\title{
The efficiency of energy utilization in growing cattle consuming fresh perennial ryegrass (Lolium perenne cv. Melle) or white clover (Trifolium repens cv. Blanca)
}

\author{
BY S. B. CAMMELL, D. J. THOMSON, D. E. BEEVER, \\ M. J. HAINES, M. S. DHANOA AND M. C. SPOONER \\ The Grassland Research Institute, ${ }^{*}$ Hurley, Near Maidenhead, \\ Berkshire SL6 5LR
}

(Received 24 May 1985 - Accepted 20 January 1986)

1. Twenty Friesian steers (225 kg live weight) were fed on mid- (M) (June-July) and late- (L) (AugustSeptember) season crops of either fresh perennial ryegrass (Lolium perenne cv. Melle) (G) or white clover (Trifolium repens $\mathrm{cv}$. Blanca) (C). Each of the forage diets was offered at three restricted planes of nutrition above maintenance to compare the effect of forage species on the efficiency of energy utilization. All diets were harvested daily from swards of regrowth forage of intended equivalent digestibility.

2. Faecal and urine excretions were measured for 7 and $5 \mathrm{~d}$ respectively, followed by two consecutive $24 \mathrm{~h}$ measurements of methane, carbon dioxide and oxygen exchange in open-circuit respiration chambers.

3. The apparent digestibility of the energy in perennial ryegrass $(0.759)$ was marginally higher $(P<0.01)$ than that in white clover $(0.748)$; the mid- and late-season forages were of $\operatorname{similar}(P>0.05)$ digestibilities. Metabolizable energy (ME): digestible energy (DE) in diet $\mathrm{G}(0.837)$ was significantly $(P<0.001)$ different from that in diet $\mathrm{C}$ $(0 \cdot 812)$. The partition of energy losses when expressed as MJ/GJ gross energy intake (GEI) indicated that energy lost as methane was not significantly different $(P>0.05)$ either between forages (G 62.8, C 63.4) or between seasons (M 63.2, L 63.1). Energy excretion in urine was higher for cattle fed on diet C (77.5) compared with diet $\mathbf{G}(60.5)(P<0.001)$. Heat production was similar $(P>0.05)$ between forages $(\mathrm{G} 480, \mathrm{C} 478)$, but lower $(P<0.01)$ for $L(471)$ compared with $M(486)$. Energy retention (by difference) was lower $(P<0.001)$ for diet $C(132)$ than $\mathrm{G}(156)$ and for $M(138)$ than $\mathrm{L}(149)(P<0.05)$.

4. Parallel-line analysis of unscaled ME intake (MEI) in relation to retained energy $(\mathrm{RE} ; \mathrm{MJ} / \mathrm{d})$ indicated that the efficiency of utilization $\left(k_{\mathrm{f}}\right)$ was similar $(P>0.05)$ between perennial ryegrass $(0.42)$ and white clover $(0 \cdot 46)$. Linear extrapolation of the values to zero energy retention indicated that maintenance requirements of $M E$ $\left(E_{\mathrm{m}} ; \mathrm{MJ} / \mathrm{d}\right)$ were 23.3 for diet $\mathrm{G}$ and 28.8 for diet $\mathrm{C}$. The extrapolated $E_{\mathrm{m}}$ when expressed in relation to a measured fasting heat production (FHP) of $22 \cdot 8$ (MJ/d) resulted in a derived efficiency of utilization of ME for maintenance $\left(k_{\mathrm{m}}\right)$ of $0.97(\mathrm{G})$ and $0.79(\mathrm{C})$, suggesting an underestimate of $E_{\mathrm{m}}$ for diet $\mathrm{G}$.

5. Asymptotic exponential curves (representing the law of diminishing returns) were fitted to the unscaled values, $\mathrm{MEI}$ and $\mathrm{RE}(\mathrm{MJ} / \mathrm{d})$, and extrapolated to zero energy retention and zero energy intake. The derived estimates of FHP (MJ/d) $18.0(\mathrm{G})$ and $22.0(\mathrm{C})$ were not significantly different $(P>0.05)$ from the observed value of $22.8 \mathrm{MJ} / \mathrm{d}$. Using the measured FHP as additional data points, the exponential model accounted for significantly more variance $(P<0.001)$ compared with the linear regression method of analysis. Exponential analysis resulted in estimates of $E_{\mathrm{m}}(\mathrm{MJ} / \mathrm{d})$ of 29.04 for diet $\mathrm{G}$ and 31.80 for $\mathrm{C}$. The $k_{\mathrm{m}}$ for each forage was calculated, assuming linearity of response, as $0.78(\mathrm{G})$ and $0.72(\mathrm{C})$. The calculation of $k_{\mathrm{f}}$ at fixed positions on the exponential curve related to MEI (expressed as multiples of $E_{m}$ ) indicated that above $1.65 E_{m}, k_{p}$ was significantly higher for $C$ than $\mathrm{G}(P<0.05)$. With increasing plane of nutrition $k_{\mathrm{f}}$ declined from 0.53 to $0.29(\mathrm{G})$ and 0.55 to $0.36(\mathrm{C})$ over the MEI range measured during the experiment.

Perennial ryegrass (Lolium perenne; $\mathrm{G}$ ) is the principal sown grass and makes a significant contribution to the energy and protein which ruminant livestock in the UK derive annually from forages. White clover (Trifolium repens; C) differs chemically in most respects from $\mathrm{G}$ and in particular has a higher protein and a lower cell wall content. Several studies have indicated that the productive potential of $\mathrm{C}$ is higher than that of grass of equivalent digestibility for both growth (Rae et al. 1963; Thomson, 1979) and lactation (Rogers et al. 1979; Gibb \& Treacher, 1983; Thomson et al. 1985).

The improved performance of animals fed on $\mathrm{C}$ has been ascribed in part to a higher

* Now The Animal and Grassland Research Institute. 
voluntary intake (Ulyatt et al. 1977), to an enhanced supply of absorbed protein (MacRae \& Ulyatt, 1974; Ulyatt et al. 1980; Beever et al. 1985) and to an enhanced utilization of metabolizable energy (ME) for growth and fattening (Joyce \& Newth, 1967; Rattray \& Joyce, 1974).

The present work was undertaken as part of a programme to investigate the nutritive value of fresh grass and legume forages to identify and quantify the factors contributing to the improved animal production obtained by feeding $C$. The partition of energy loss was examined, including estimation of heat production by open-circuit calorimetry, to determine the efficiency of energy utilization by young cattle given both mid- (M) and late- (L) season cuts of either fresh $\mathrm{G}$ or $\mathrm{C}$.

\section{MATERIALS AND METHODS}

\section{Diets}

Two forages: $\mathrm{G}$ (cv. Melle) and C (cv. Blanca) were harvested from swards which were 5 and 3 years old respectively. In early spring $G$ received $60 \mathrm{~kg}$ nitrogen/ha of compound fertilizer (N-phosphorus-potassium; 20:10:10, w/w), and $\mathrm{C}$ received an equivalent amount of $P$ and $K$, but no $N$ was applied to this crop at any time throughout the season. The resulting primary growths of $\mathrm{G}$ and $\mathrm{C}$ were removed by mechanical harvesting in late May and mid-June respectively and the two fields were then appropriately divided into plots to allow successive 4 week $(\mathrm{G})$ and 3 week $(\mathrm{C})$ regrowths to be established, with the objective of harvesting forage from $\mathrm{G}$ and $\mathrm{C}$ of equivalent digestibility. Following each harvest the grass swards received an extra $60 \mathrm{~kg} \mathrm{~N} / \mathrm{ha}$. All swards were irrigated in an attempt to constrain soil moisture deficit.

\section{Pre-experimental management of animals}

Twenty-two 10-d-old Friesian male castrate calves (mean live weight (LW) $49 \mathrm{~kg}$ ) were uniformly reared on milk-substitute to 6 weeks of age followed by hay and concentrates to 23 weeks of age. Between 23 and 26 weeks all calves were given a mixture of $\mathrm{G}$ and $\mathrm{C}$ $(50: 50, \mathrm{w} / \mathrm{w})$ at a fixed level of intake of $26 \mathrm{~g}$ dry matter $(\mathrm{DM}) / \mathrm{kg} \mathrm{LW}$. The $\mathrm{LW}$ range at 26 weeks of age was $170-230 \mathrm{~kg}$ (mean $190 \mathrm{~kg}$ ).

At 18 weeks of age all animals were paired on the basis of $L W$ and a provisional allocation made to either $\mathrm{G}$ or $\mathrm{C}$ treatments. Subsequently, within each group the animals were blocked according to $\mathrm{LW}$, and randomly allocated to three levels of feeding. Between weeks 18 and 23 all animals were allowed access to metabolism cages and the respiration chambers so that they could become accustomed to the procedures before the start of experimental measurements. At week 26 the experimental diets were introduced at the designated feeding levels to all animals except the two intended for measurement of fasting heat production (FHP) which were maintained on a $\mathrm{G}$ and $\mathrm{C}$ mixture at the median level of feeding. All animals were housed on partially slatted floor pens except during the faecal and urine collection periods.

\section{Experimental design}

The experiment was conducted over a period of $106 \mathrm{~d}$ as part of a production slaughter balance experiment. Due to the extended feeding period required for the comparative slaughter study, the two forage species $G$ and $C$ could be considered as mid-season (M), given during June and July, days 14-52 of the experiment (MG and MC respectively); and late season (L), given during August and September, days 53-91 of the experiment (LG and LC respectively). Each crop was offered at three levels of feeding: 20, 23 and $26 \mathrm{~g} \mathrm{DM} / \mathrm{kg} \mathrm{LW}$ (levels 1, 2 and 3 respectively). A total of four animals were allocated to level 1 and three to each of levels 2 and 3 , the remaining two animals were retained separately 
for subsequent estimates of FHP. No further reallocation of animals was made for the duration of the experiment and all animals were used for the measurement of respiratory exchange with the exception of one animal on forage $\mathrm{C}$ which died from bloat. Two respiration chambers were available, consequently faecal and urine balance measurements were undertaken immediately before respiratory exchange in a sequential order appropriate to the age of the regrowth herbage on the plots and the designated $\mathrm{M}$ and $\mathrm{L}$ seasons.

\section{Experimental procedures}

The two forages were harvested separately each morning at 07.30 hours. The crops were cut using a rotary drum mower and the cut material was then immediately harvested without chopping using a direct pick-up forage wagon with the stationary cutting knives removed. After delivery to the animal house a $5 \mathrm{~kg}$ representative sample of each forage was taken and used to provide two $100 \mathrm{~g}$ samples for rapid DM determination using a modified microwave oven. During feed weighing, representative bulked samples of each forage were taken and subsequently four $500 \mathrm{~g}$ samples were prepared for DM determination by oven drying at $100^{\circ}$ for $24 \mathrm{~h}$. A further $1 \mathrm{~kg}$ subsample of each forage was immediately frozen for subsequent chemical analysis.

Daily fresh weight allowances were calculated on the basis of the initial rapid estimates of DM content and the appropriate LW of the animals. The forages were offered to the animals in two equal amounts at 09.30 and 16.00 hours. The forage for the afternoon feeding was held at $2^{\circ}$ in a cold room. The animals on diet $\mathrm{C}$ received an oral dose $(5 \mathrm{ml}$ at each feed) of Poloxalene (Smith, Kline \& French, Welwyn Garden City, Herts.) to control bloat. Feed refusals, where they occurred, were removed daily before the 09.30 hours feeding and dried at $100^{\circ}$ for $24 \mathrm{~h}$ to determine DM content.

LW were recorded weekly on two consecutive days between 07.30 and 08.30 hours, with the exception of the animals on faecal and urine balance and respiratory exchange measurements, and food allowance was adjusted weekly according to the predetermined levels of feeding. No adjustments to food allowance were made during balance and calorimetric measurements.

Faeces and urine were collected for seven and five consecutive days respectively, before entry into the respiration chambers, using the procedures decribed by Cammell (1977). The animals were then placed in open-circuit respiration chambers for $3 \mathrm{~d}$, comprising day 1 for acclimatization and days 2 and 3 for consecutive $24 \mathrm{~h}$ measurements of respiratory exchange. Respiration measurements were conducted as described by Cammell et al. (1981) with the exception that the chambers used were constructed of double-skin steel insulated panels and had an internal volume of $15 \mathrm{~m}^{3}$. Additionally each chamber had a recirculatory air conditioning system to provide environmental control within a temperature range of $18 \pm 2^{\circ}$ and relative humidity (RH) of $60 \pm 10 \%$. Gaseous composition of the in- and out-going air from the respiration chambers was measured using dual-channel infra-red (Analytical Development Co. Ltd, Hoddesdon, Herts.) and paramagnetic analysers (Taylor Instrument Analytics Ltd, Crowborough, Sussex). Measurement of the volume of gases leaving each chamber and the method of sampling was as previously described by Cammell et al. (1981). Measurements of FHP were determined on days 1-4, 51-54 and 103-106 of the experiment, using procedures described by Blaxter (1962), with the exception that total length of fast was $96 \mathrm{~h}$ and included two consecutive days of measurement between 48 and $96 \mathrm{~h}$.

\section{Preparation and analysis of samples}

All samples of feed taken at the time of weighing were freeze-dried and ground through a small laboratory mill. For each animal the faeces voided daily were mixed and a representative sample comprising $10 \%$ of total daily fresh weight was withdrawn and 
accumulated for $7 \mathrm{~d}$ in a cold store at $-5^{\circ}$. The bulked samples were thoroughly mixed after thawing and part $(4 \times 500 \mathrm{~g})$ was dried at $100^{\circ}$ for $48 \mathrm{~h}$ to determine DM content and a further portion $(500 \mathrm{~g})$ was freeze-dried to provide a sample, after grinding, for chemical analysis. Samples of feed and faeces were analysed for organic matter (ashing to $550^{\circ}$ overnight), total $\mathrm{N}$ (micro-Kjeldahl) and gross energy (GE; adiabatic calorimetry) contents. Feed samples were further analysed for in vitro organic matter digestibility in DM (DOMD) (Tilley \& Terry, 1963) and buffer-insoluble N content (Siddons \& Paradine, 1981).

Acidified urine samples were accumulated for $5 \mathrm{~d}$ on a fresh basis $(1 \%$ of total daily output) and urinary $\mathrm{N}$ content was determined by micro-Kjeldahl, using fresh samples. Urinary energy contents were estimated after the samples had been dried under reduced pressure in a rotary evaporator at $40^{\circ}$ followed by resolubilization in a minimal quantity of distilled water to permit total combustion (after freeze-drying in a thin-walled polyethylene container) in an adiabatic bomb calorimeter (R. A. Terry, personal communication).

\section{Calculations}

The sequential measurements of faecal and urinary output during the balance trials and the succeeding measurements of respiratory exchange by open-circuit calorimetry were associated with small changes in the composition of both the fresh forages. The consequent effects on faecal (FE) and urinary energy (UE) output necessitated a method of estimation for the days of respiratory exchange.

The best relation for the prediction of FE output was obtained from a multiple regression analysis of the FE losses during balance measurements incorporating GE intake (GEI) and DOMD. UE output was similarly predicted using UE losses during balance measurements, GEI, DOMD and N intake (NI). The regressions for season within each forage were derived, tested for differences in slope and intercept and combined where appropriate. These estimates were then used together with the observed values for methane production to calculate ME content of the diets and the ME intake (MEI).

Heat production (HP) was calculated according to Brouwer (1965), from the observed values for methane, oxygen and carbon dioxide exchange and derived urinary $\mathrm{N}$ excretion applicable to NI during the days of respiratory exchange. This latter relation was determined from a regression of all observed values for urinary N output and NI. Retained energy (RE) was calculated as the difference between MEI and HP.

\section{Statistical analysis}

Results for the chemical composition, intake, digestibility coefficients (as measured), the partition of energy losses between faeces and urine (derived from eqns (3) and (4), p. 674), methane, heat output and energy retention were analysed as a $2 \times 2$ factorial design (i.e. two forages $G$ and $C$, two seasons $M$ and $L$ ) and adjusted for level of feeding using a regression analysis of variance.

Two methods of analysis were used to examine the data for RE and MEI: linear regression and exponential curve analysis. The exponential method followed the general model:

$$
R E=P_{3}\left[1-\exp \left(-P_{1}\left(M E I-P_{2}\right)\right)\right],
$$

where $\mathrm{P}_{1}$ is the curvature or specific rate, $\mathrm{P}_{2}$ is equivalent to $E_{\mathrm{m}}, \mathrm{P}_{3}$ is the asymptote and $P_{3}\left[1-\exp \left(P_{1} P_{2}\right)\right]$ is the estimation of FHP (F2). Differentiation of eqn (1) with respect to MEI allows calculation of the efficiency of utilization, $k_{\mathrm{f}}$, at any value of MEI, i.e. $k_{\mathrm{f}}=\mathrm{d}(\mathrm{RE}) / \mathrm{d}(\mathrm{MEI})$ thus:

$$
k_{\mathrm{f}}=\mathrm{P}_{1} \mathrm{P}_{3} \exp \left[-\mathrm{P}_{1}\left(\mathrm{MEI}-\mathrm{P}_{2}\right)\right] \text {. }
$$

The relations used to predict FE and UE were examined using mean square prediction error (MSPE) analysis (Neal et al. 1984) and the Bootstrap method (Efron, 1979). 
Table 1. The chemical composition of the mid- $(M)$ and late- $(L)$ season cuts of fresh perennial ryegrass (Lolium perenne $c v$. Melle) and white clover (Trifolium repens $c v$. Blanca)

(Values expressed as $\mathrm{g} / \mathrm{kg}$ dry matter (DM) unless otherwise stated)

\begin{tabular}{|c|c|c|c|c|c|c|c|}
\hline & \multicolumn{2}{|c|}{ Perennial ryegrass } & \multicolumn{2}{|c|}{ White clover } & \multirow[b]{2}{*}{ SEM } & \multicolumn{2}{|c|}{$\begin{array}{l}\text { Statistical } \\
\text { significance } \\
\text { of effect of: }\end{array}$} \\
\hline & $\mathbf{M}$ & $\mathrm{L}$ & $\mathbf{M}$ & $\mathrm{L}$ & & Forage & Season \\
\hline $\mathrm{DM}(\mathrm{g} / \mathrm{kg})$ & $185 \cdot 7$ & $162 \cdot 7$ & $150 \cdot 8$ & 126.8 & $3 \cdot 22$ & *** & $* * *$ \\
\hline Ash & 96.8 & 97.2 & 94.5 & 101.9 & 1.59 & NS & $* *$ \\
\hline Nitrogen & $25 \cdot 7$ & $29 \cdot 9$ & $42 \cdot 9$ & $44 \cdot 8$ & 0.58 & $* * *$ & $* * *$ \\
\hline Insoluble $\mathrm{N}$ & 22.0 & $25 \cdot 9$ & 34.8 & 37.8 & $0 \cdot 50$ & $* * *$ & $* * *$ \\
\hline \multicolumn{8}{|l|}{ Gross energy: } \\
\hline $\mathrm{MJ} / \mathrm{kg} \mathrm{DM}$ & $18 \cdot 0$ & $18 \cdot 6$ & $18 \cdot 8$ & $19 \cdot 1$ & 0.05 & $* * *$ & $* * *$ \\
\hline $\mathrm{MJ} / \mathrm{kg} \mathrm{OM}$ & $20 \cdot 0$ & $20 \cdot 6$ & $20 \cdot 8$ & $21 \cdot 2$ & 0.06 & $* * *$ & $* * *$ \\
\hline In vitro $\mathrm{DOMD} \dagger$ & 0.702 & 0.687 & 0.681 & 0.675 & 0.005 & $* * *$ & $* * *$ \\
\hline In vitro $\mathrm{DOMD}_{*}^{\dagger}$ & 0.697 & 0.683 & 0.672 & 0.676 & 0.005 & $* * *$ & $* * *$ \\
\hline
\end{tabular}

OM, organic matter; DOMD, digestibility of organic matter in dry matter; NS, not significant.

** $P<0.01, * * * P<0.001$.

$\dagger$ Mean value during faecal and urine balance measurements.

\$ Mean value during respiratory exchange measurements.

\section{RESULTS}

The chemical composition of the diets is presented in Table 1.

Significant differences were found between the forages $\mathrm{G}$ and $\mathrm{C}(P<0.001)$ and between the seasons $\mathrm{M}$ and $\mathrm{L}(P<0.01)$ in all chemical constituents with the exception of the ash content. The results demonstrate the inherent differences in composition of the two forages. The $\mathrm{N}$ content of $\mathrm{C}$ was higher than that in $\mathrm{G}$; also GE content, both on a DM and organic matter basis, was higher than that of the grass. The in vitro DOMD results are given as weighted means for each forage season and represent the mean values observed during the consecutive periods of faecal/urine balance and respiratory exchange measurements. The values for in vitro DOMD for the days of respiratory exchange were not significantly different from those for faecal/urine balance, except for the MC values $(P<0.001)$. The

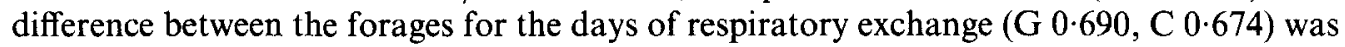
primarily due to the difference between the $M$ forages ( $G 0.697, C 0.672$ ), as a result of water stress which appeared to induce earlier flowering of the $C$ crop. This resulted in the harvested material containing a higher proportion of mature inflorescence and their supporting stems which had a lower in vitro digestibility than the leaf and petiole components (Gibb \& Treacher, 1983). The significant $(P<0.01)$ seasonal effect in the ash content was associated with a reduction in the cutting height of the forages and the consequent increase in soil contamination especially as seen on diet LC. There was a significant $(P<0.001)$ increase in the $\mathrm{N}$ contents of both forages from $\mathrm{M}$ - to L-season cuts. Chemical analysis of fibre was restricted to feed samples from the comparative slaughter study and the overall values for $\mathrm{G}$ and $\mathrm{C}$ respectively $(\mathrm{g} / \mathrm{kg} \mathrm{DM})$ for neutral-detergent fibre were 426.7 and 216.1 , acid-detergent fibre 266.2 and 210.9 , lignin 26.7 and 38.2 , pectin 7.8 and 39.9 . The values were significantly different $(P<0.001)$ between $\mathrm{G}$ and $\mathrm{C}$.

The apparent digestibility of the organic matter (OMD), N (ADN) and GE (ADE) at the three restricted levels of feeding are given in Table 2. The ADN values of $G$ were significantly $(P<0.001)$ lower, and OMD and ADE values significantly $(P<0.05$ and 0.01 respectively) higher than $C$. This latter effect was primarily due to differences between the 
Table 2. Coefficients of apparent digestibility of the organic matter, nitrogen and energy in mid- $(M)$ and late- $(L)$ season cuts of fresh perennial ryegrass (Lolium perenne cv. Melle) and white clover (Trifolium repens $c v$, Blanca) given to Friesian steers at three restricted levels of feeding

\begin{tabular}{|c|c|c|c|c|c|c|c|c|c|}
\hline & \multirow{2}{*}{$\begin{array}{c}\text { Level } \\
\text { of } \\
\text { feedingt }\end{array}$} & \multicolumn{2}{|c|}{$\begin{array}{l}\text { Perennial } \\
\text { ryegrass }\end{array}$} & \multicolumn{2}{|c|}{$\begin{array}{l}\text { White } \\
\text { clover }\end{array}$} & \multirow[b]{2}{*}{ SEM } & \multicolumn{3}{|c|}{$\begin{array}{c}\text { Statistical significance } \\
\text { of effect of: }\end{array}$} \\
\hline & & $\mathbf{M}$ & $\mathbf{L}$ & $\mathbf{M}$ & $\mathrm{L}$ & & Forage & Season & Level \\
\hline Organic matter & $\begin{array}{l}1 \\
2 \\
3\end{array}$ & $\begin{array}{l}0.812 \\
0 \cdot 805 \\
0.806\end{array}$ & $\begin{array}{l}0.811 \\
0.798 \\
0.791\end{array}$ & $\begin{array}{l}0.789 \\
0.798 \\
0.761\end{array}$ & $\left.\begin{array}{l}0.804 \\
0.799 \\
0.777\end{array}\right)$ & 0.0107 & * & NS & * \\
\hline $\mathrm{N}$ & $\begin{array}{l}1 \\
2 \\
3\end{array}$ & $\begin{array}{l}0.681 \\
0.693 \\
0.690\end{array}$ & $\begin{array}{l}0.766 \\
0.754 \\
0.711\end{array}$ & $\begin{array}{l}0.776 \\
0.789 \\
0.771\end{array}$ & $\left.\begin{array}{l}0.811 \\
0.801 \\
0.798\end{array}\right)$ & 0.0173 & $* * *$ & $* * *$ & NS \\
\hline Energy & $\begin{array}{l}1 \\
2 \\
3\end{array}$ & $\begin{array}{l}0.763 \\
0.763 \\
0.755\end{array}$ & $\begin{array}{l}0.768 \\
0.753 \\
0.749\end{array}$ & $\begin{array}{l}0.748 \\
0.748 \\
0.715\end{array}$ & $\begin{array}{l}0.759 \\
0.758 \\
0.758\end{array}$ & 0.0066 & $* *$ & NS & $* *$ \\
\hline
\end{tabular}

NS, not significant. ${ }^{*} P<0.05,{ }^{* *} P<0 \cdot 01,{ }^{* *} P<0.001 . \quad+$ For details, see p. 670 .

$M$ forages where early flowering induced by water stress was associated with declining in vitro digestibility of the MC forage. Significant $(P<0.001)$ differences due to season were restricted to ADN, where $\mathrm{L}$ crops were higher than $\mathrm{M}$. Significant differences $(P<0.05$ and 0.01 respectively) due to level of feeding were apparent for both OMD and ADE.

Predictive relations for FE and UE excretion from forages $\mathrm{G}$ and $\mathrm{C}$ are given in Table 3. These were derived as previously described from the pooled observed values from balance measurements. The use of these individual forage relations did not significantly improve $(P>0.05)$ the variance accounted for when compared with the combined $\mathrm{G}$ and $\mathrm{C}$ overall relations, eqns (3) and (4):

$\mathrm{FE}=0 \cdot 2473 \mathrm{GEI}-44 \cdot 7908 \mathrm{DOMD}+30 \cdot 3758(r 0 \cdot 861$, residual SD (RSD) $1 \cdot 45928)$,

$\mathrm{UE}=0.0257 \mathrm{GEI}-3.1336 \mathrm{DOMD}+0.0223 \mathrm{NI}+2.0974(r 0.850$, RSD 0.62883),

where FE, UE and GEI are expressed as $\mathrm{MJ} / \mathrm{d}$ and $\mathrm{NI}$ as $\mathrm{g} / \mathrm{d}$.

The possibility of significant differences in the spread of predicted values of either $\mathrm{FE}$ or UE from the overall relations when compared with individual relations for $\mathrm{G}$ and $\mathrm{C}$, were examined using MSPE analysis and the Bootstrap method.

MSPE results showed non-significant biases (individual - overall) $(P>0.05)$ for both $\mathrm{FE}$ and UE predictions. For $G$ and $C$ respectively, the bias in the prediction of $F E(M J / d)$ was -0.682 (SE 0.3806), $-0.122($ SE 0.1202) and for UE $(\mathrm{MJ} / \mathrm{d})+0.235(\mathrm{SE} 0.3650)$, $-0 \cdot 115$ (SE 0.1293).

The Bootstrap method also indicated no significant differences $(P>0.05)$ between the predictive relations. The coefficients of variation for eqn (3) were (G) 8.674 , (C) 8.674 which were lower than the individual forage relations (Table 3) (G) 9.464, (C) 8.787. The coefficients of variation for eqn (4) were also lower (G) 8.844 , (C) 4.917 than the individual relations $(\mathrm{G}) 13 \cdot 755$, (C) $5 \cdot 454$.

As a result of these statistical analyses the overall relations as given in eqns (3) and (4) were used to predict FE and UE as presented in Table 4.

During the days of respiratory exchange, the measured GEI, methane and heat energy output (MJ/GJ GEI), together with FE and UE outputs derived from eqns (3) and (4), and $\mathrm{LW}$ derived from the relation of LW $v$. time-period of respiratory exchange have been 
Table 3. The regression equations relating (a) energy loss $(\mathrm{Y} ; M J / d)$ in faeces to gross energy intake $(G E I ; M J / d)$ and in vitro digestibility of organic matter in dry matter $(D O M D)$, and (b) energy loss $(\mathrm{Y} ; M J / d)$ in urine to $G E I$, in vitro DOMD and nitrogen intake $(N I ; g / d)$ for Friesian steers fed on fresh perennial ryegrass (Lolium perenne $c v$. Melle) and white clover (Trifolium repens $c v$. Blanca)

(The values are combined for mid-and late season and three levels of feeding)

\begin{tabular}{|c|c|c|}
\hline & Perennial ryegrass & White clover \\
\hline (a) Fueces & $\begin{aligned} Y= & 0.2679 \mathrm{GEI}-13.5128 \mathrm{DOMD} \\
+ & 6.9365 \\
& r 0.865, \text { RSD } 1.31957\end{aligned}$ & $\begin{aligned} Y= & 0.2447 \mathrm{GEI}-55.4003 \text { DOMD } \\
& +37.6281 \\
& r 0.866, \text { RSD } 1.67575\end{aligned}$ \\
\hline (b) Urine & $\begin{array}{c}Y=0.0008 \mathrm{GEI}+28.3934 \text { DOMD } \\
+0.0471 \mathrm{NI}-20.7221 \\
r 0.738, \text { RSD } 0.77576\end{array}$ & $\begin{aligned} Y= & 0.0509 \mathrm{GEI}+1.6273 \text { DOMD } \\
+ & 0.0082 \mathrm{NI}-0.3892 \\
& r 0.896, \mathrm{RSD} 0.43521\end{aligned}$ \\
\hline
\end{tabular}

RSD, residual SD.

Table 4. The live weight $(\mathrm{kg})$, gross energy intake $(G E I ; M J / d)$ and the loss of energy in faeces (eqn (3)) $\dagger$, urine (eqn (4)) $\uparrow$, methane and heat and the energy retention $(M J / G J G E I)$ during the days of respiratory exchange by Friesian steers fed mid- $(M)$ and late- $(L)$ season cuts of fresh perennial ryegrass (Lolium perenne $c v$. Melle) and white clover (Trifolium repens cv. Blanca)

(Values are presented as means of three levels of feeding)

\begin{tabular}{|c|c|c|c|c|c|c|c|}
\hline & \multicolumn{2}{|c|}{$\begin{array}{c}\text { Perennial } \\
\text { ryegrass }\end{array}$} & \multicolumn{2}{|c|}{$\begin{array}{l}\text { White } \\
\text { clover }\end{array}$} & \multirow[b]{2}{*}{ SEM } & \multicolumn{2}{|c|}{$\begin{array}{c}\text { Statistical } \\
\text { significance } \\
\text { of effect of: }\end{array}$} \\
\hline & M & $\mathrm{L}$ & M & $\mathrm{L}$ & & Forage & Season \\
\hline Live wt & 229 & 258 & 217 & 249 & $3 \cdot 3$ & $* *$ & $* * *$ \\
\hline GEI & $85 \cdot 6$ & $100 \cdot 2$ & $84 \cdot 4$ & $101 \cdot 6$ & 1.34 & NS & $* * *$ \\
\hline \multicolumn{8}{|l|}{ Energy loss as: } \\
\hline Faeces & 236.9 & $244 \cdot 3$ & $254 \cdot 3$ & 245.9 & $2 \cdot 91$ & $* * *$ & NS \\
\hline Urine & $57 \cdot 5$ & $63 \cdot 4$ & $76 \cdot 6$ & $78 \cdot 4$ & $0 \cdot 70$ & $* * *$ & * \\
\hline Methane & $64 \cdot 2$ & $61 \cdot 5$ & $62 \cdot 1$ & $64 \cdot 8$ & 0.62 & NS & NS \\
\hline Heat & $483 \cdot 7$ & $475 \cdot 8$ & $488 \cdot 3$ & $467 \cdot 1$ & 3.80 & NS & $* *$ \\
\hline Energy retention & $157 \cdot 4$ & 154.9 & $119 \cdot 4$ & $143 \cdot 8$ & $4 \cdot 48$ & $* * *$ & $*$ \\
\hline
\end{tabular}

NS, not significant. $\quad{ }^{*} P<0.05,{ }^{* *} P<0.01,{ }^{* * *} P<0.001 . \quad \dagger$ For details, see p. 674

pooled across levels and are presented in Table 4. GEI was similar for both forages, but was significantly higher $(P<0.001)$ for the $L$ crops, although scaling for $L W$ removed this effect. The mean values of FE and UE (MJ/GJ GEI) were higher $(P<0.001)$ for C $(250,78)$ than $G(241,60)$, but neither forage nor season had any significant effect on methane energy output (MJ/GJ GEI).

The ME contents (MJ/ $\mathrm{kg} \mathrm{DM}$ ) of the forages were obtained by deducting the FE and UE outputs, calculated from eqns (3) and (4), and the methane energy output from GEI (observed), and dividing by DM intake. The values were 11.98 and 11.60 for diets MG and LG respectively and 11.59 and 11.53 (SE 0.145 ) for $\mathrm{MC}$ and $\mathrm{LC}$. There was a significant $(P<0.05)$ difference between forages but no effect due to season $(P>0.05)$.

ME:DE of the forages were 0.840 and 0.835 for MG and LG, 0.814 and 0.810 for MC 
Table 5. (a) The estimated coefficients relating to the partition of the metabolizable energy of perennial ryegrass (Lolium perenne $c v$. Melle) and white clover (Trifolium repens $c v$. Blanca) according to eqn ( 1$) \dagger$, and $(b)$ the predicted efficiency of utilization $\left(\mathrm{k}_{f}\right)$ according to eqn (2) † at several levels of metabolizable energy intake $(M J / d)$

\begin{tabular}{|c|c|c|c|c|c|}
\hline & \multicolumn{2}{|c|}{ Perennial ryegrass } & \multicolumn{2}{|c|}{ White clover } & \multirow{2}{*}{$\begin{array}{c}\text { Statistical } \\
\text { significance }\end{array}$} \\
\hline & & SEM & & SEM & \\
\hline \multicolumn{6}{|l|}{ (a) Parameter } \\
\hline$P_{1}\left(\times 10^{-3}\right)$ & $15 \cdot 12$ & 3.280 & $10 \cdot 61$ & $2 \cdot 080$ & - \\
\hline$P_{2}$ & $29 \cdot 04$ & 1.407 & 31.79 & 0.832 & - \\
\hline $\mathrm{P}_{3}$ & $41 \cdot 40$ & 8.198 & 56.73 & $10 \cdot 365$ & -- \\
\hline $\mathrm{F}_{2}$ & $22 \cdot 83$ & 2.703 & $22 \cdot 77$ & $2 \cdot 627$ & - \\
\hline \multicolumn{6}{|c|}{ (b) Metabolizable energy intake } \\
\hline 40 & 0.530 & 0.0152 & 0.552 & 0.0222 & NS \\
\hline 50 & 0.456 & 0.0064 & 0.496 & 0.0193 & $*$ \\
\hline 60 & 0.392 & 0.0040 & 0.446 & 0.0166 & * \\
\hline 70 & 0.337 & 0.0091 & 0.401 & 0.0142 & * \\
\hline 80 & 0.289 & 0.0139 & 0.361 & 0.0121 & * \\
\hline
\end{tabular}

NS, not significant. $\quad * P<0.05 . \quad+$ For details see p. 672.

and $\mathrm{LC}$ respectively. There was a significant $(P<0.001)$ difference between forages and a small but significant $(P<0.05)$ effect of season. Heat production $(\mathrm{MJ} / \mathrm{GJ}$ GEI) was not significantly different between the forages; there was, however, a significant $(P<0.01)$ effect of season which was due primarily to the lower value recorded on diet LC. Energy retention (MJ/GJ GEI) was significantly affected by forage (G 156, C 132;P<0.001) and season (M 138, L 149; $P<0.05$ ), resulting from the low value (119) measured on the animals receiving diet $\mathrm{MC}$ due to higher $\mathrm{FE}$ and heat energy outputs (MJ/GJ GEI). The linear relations of $\mathrm{RE}$ on $\mathrm{MEI}(\mathrm{MJ} / \mathrm{d})$ were:

$$
\begin{aligned}
& \mathrm{G}: \mathrm{RE}=0.4169 \mathrm{MEI}-9.7010 \quad(r 0.902, \mathrm{RSD} 1.636), \\
& \mathrm{C}: \mathrm{RE}=0.4616 \mathrm{MEI}-13.2995(r 0.964, \text { RSD 1.451) }
\end{aligned}
$$

No significant differences were found between forages although a small effect of season was observed. Scaling RE and MEI values by metabolic LW (LW ${ }^{\mathbf{0} 75}$ ) did not significantly improve the variance accounted for by the linear relations of the unscaled values. Linear extrapolation of eqns (5) and (6) indicated maintenance requirements $\left(E_{\mathrm{m}}\right)(\mathrm{MJ} / \mathrm{d})$ at zero energy retention of $\mathrm{G} 23 \cdot 3$ and $\mathrm{C} 28 \cdot 8$. The measured mean value for $\mathrm{FHP}$ was $22 \cdot 8 \mathrm{MJ} / \mathrm{d}$. This value in relation to linear estimates of $E_{\mathrm{m}}$ for $\mathrm{G}$ would imply an efficiency of utilization of ME for maintenance, $k_{\mathrm{m}}$, of 0.97 , suggesting an underestimate of $E_{\mathrm{m}}$.

The unscaled RE and MEI values were applied to the exponential model (eqn (1)) excluding the measured value of FHP. This resulted in estimates of FHP of G 18.0 and $\mathrm{C} 22.0 \mathrm{MJ} / \mathrm{d}$, which were not significantly different either between forages or from the mean measured value of $22 \cdot 8$. Measured FHP was then used as an additional data point and the model re-run without constraining the curve through measured FHP. The unscaled RE and MEI values and the derived curve shown in Fig. 1 were used to obtain the parameters and predictions described in Table 5 . The variance accounted for was significantly $(P<0.001)$ improved in comparison with the linear models (eqns (5) and (6)).

Parameter $\mathrm{P}_{1}$ (eqn (1)) represents the rate of decline of $k_{\mathrm{f}}$ with increasing MEI. Fitting a common $P_{1}$ to diets $G$ and $C$ resulted in a significant increase $(P<0.05)$ in residual error variance, therefore separate curves were used for each forage. $P_{2}$ estimates the values for 
$E_{\mathrm{m}}(29.04$ and $31.80(\mathrm{MJ} / \mathrm{d})$ for $\mathrm{G}$ and $\mathrm{C}$ respectively) which were significantly $(P<0.05)$ different. The asymptote $\left(\mathrm{P}_{3}\right)$ represents the maximal potential energy retention for the forages. $\mathrm{F}_{2}$ represents FHP: $\mathrm{G} 22.83, \mathrm{C} 22.77 \mathrm{MJ} / \mathrm{d}$. The $k_{\mathrm{m}}$ values derived from FHP and $E_{\mathrm{m}}$, assuming linearity of response, were in close agreement with expected values for forage diets of similar metabolizability G $0.78, \mathrm{C} 0.72$ (Agricultural Research Council, 1980). The effect of the differences in the above parameters $\left(\mathrm{P}_{1}, \mathrm{P}_{2}, \mathrm{P}_{3}\right)$ is reflected in the derived $k_{\mathrm{f}}$ values at several levels of MEI. When calculated as multiples of $E_{\mathrm{m}}$, significant differences $(P<0.05)$ due to forage species were apparent only above $1.65 E_{\mathrm{m}}$ or $50 \mathrm{MJ} \mathrm{MEI} / \mathrm{d}$.

\section{DISCUSSION}

The objective of the present experiment was to evaluate the efficiency of energy utilization in growing cattle consuming either fresh $\mathrm{G}$ or $\mathrm{C}$ as pasture species. Due to the lack of appropriate techniques to measure accurately the ME intake of grazing animals, the experiment was conducted indoors under controlled conditions, using open-circuit respiration calorimetry.

The grass and legume forages, harvested daily in the long form, were also given in a related growth and tissue retention experiment (Thomson et al. 1983), using the same cattle, and also in a digestion and metabolism study (Cammell et al. 1983). The results of this study and the related comparative slaughter experiment permit a direct comparison between two different techniques for the measurement of RE and $k_{\mathrm{f}}$. These will be discussed in a subsequent paper.

Current methods of analysis of energy balance measurements by respiration calorimetry have embraced the main conventions of separate linear analysis of negative $\left(k_{\mathrm{m}}\right)$ and positive $\left(k_{\mathrm{f}}\right)$ energy balance, with the derivation of $k_{\mathrm{f}}$ restrained to measurements between zero energy retention and twice maintenance level of feeding.

The results from this experiment were initially analysed according to the previously mentioned conventions, expressing the nutritive value of each forage as the linear response in RE per unit increase in ME intake. Overall estimates of the values (unscaled for $\mathrm{LW}^{0.75}$ ) gave predicted values for $k_{\mathrm{f}}$ of $\mathrm{G} 0.42$ and $\mathrm{C} 0.46$ which were not significantly different. Scaling the values using $\mathrm{LW}^{0.75}$ did not either significantly alter the estimated $k_{\mathrm{f}}$ or account for more of the variation. Extrapolation of the unscaled linear values to zero energy retention gave estimated values for $E_{\mathrm{m}}$ of $\mathrm{G} 23.3$ and $\mathrm{C} 28.8 \mathrm{MJ} \mathrm{ME} / \mathrm{d}$, equivalent to 378 and $483 \mathrm{~kJ} \mathrm{ME} / \mathrm{kg} \mathrm{LW}^{0.75}$ per $\mathrm{d}$ for diets $\mathrm{G}$ and $\mathrm{C}$ respectively. The value derived for diet C was comparable to those obtained by Brierem (1953) and Van Es (1961) for growing cattle, but the value obtained for diet $\mathrm{G}$ was approximately $20 \%$ lower than would have been predicted on the basis of Agricultural Research Council (1980).

The measurement of FHP in the present study extended the range of values and permitted the calculation of $k_{\mathrm{m}}$ using the $E_{\mathrm{m}}$ as derived previously. This gave a value of 0.79 for diet $\mathrm{C}$ and 0.98 for diet $\mathrm{G}$. This latter value was considered to be unacceptable in relation to values which have been quoted for diets of similar metabolizability (Agricultural Research Council, 1980).

Previously reported studies have demonstrated that the law of diminishing returns applies to the responses in energy retention with increasing plane of nutrition (Blaxter \& Graham, 1955; Blaxter \& Boyne, 1970, 1978; Agricultural Research Council, 1980). Alternative analysis of the values was undertaken using an asymptotic exponential model (Fig. 1 and Table 5), similar to the methods of analysis previously reported by Blaxter \& Boyne (1978). The analysis enabled the values for MEI and RE to be incorporated with the predicted and measured values for FHP (unforced curve) and this was found to account for a greater proportion of the variance than the linear method. Additionally, it gave estimates of FHP 


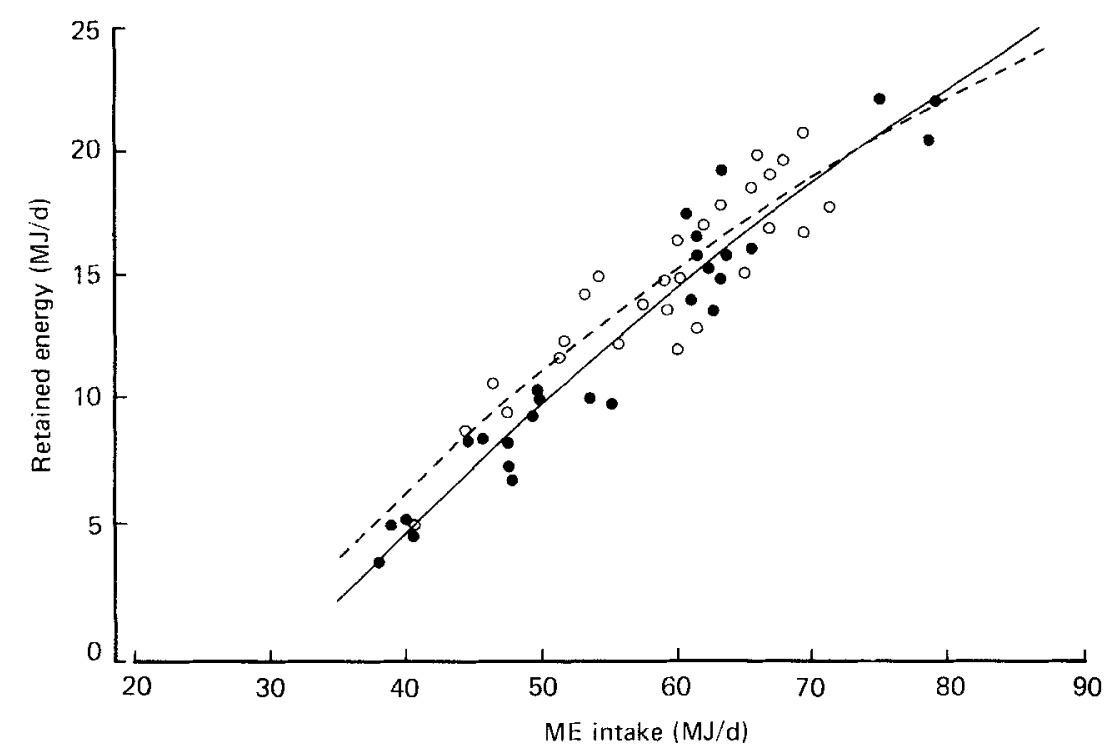

Fig. 1. The relation between retained energy $(\mathrm{O}, \mathrm{O})$ and metabolizable energy (ME) intake $(--,-\infty)(\mathrm{MJ} / \mathrm{d})$ for fresh perennial ryegrass (Lolium perenne $\mathrm{cv}$. Melle) $(\mathrm{O}, \ldots)$ and white clover (Trifclium repens $\mathrm{cv}$. Blanca) (O,-) given to Friesian steers. Each point represents an individual daily observation. The overall forage relations are calculated according to eqn (1) (see p. 672).

(22.8 and $22.7 \mathrm{MJ} / \mathrm{d}$ for $\mathrm{G}$ and $\mathrm{C}$ respectively) which agreed both with the measured values and those previously reported by Vercoe \& Frisch (1974), Webster et al. (1974) and Webster (1978) for growing cattle of similar age and $\mathrm{LW}$. The estimated values of $E_{\mathrm{m}}$ were $29 \cdot 0$ and $31.8 \mathrm{MJ} \mathrm{ME} / \mathrm{d}$ for $\mathrm{G}$ and $\mathrm{C}$ respectively. These were then used in conjunction with estimated FHP and by assuming linearity of response, values for $k_{\mathrm{m}}$ of $\mathrm{G} 0.79$ and $\mathrm{C} 0.72$ were derived which were found to be closer to theoretical expectations (Agricultural Research Council, 1980).

The scaled values $\left(\mathrm{LW}^{\mathbf{0} \cdot 75}\right)$ were similarly analysed but did not account for a significantly greater proportion of variance than the unscaled exponential analysis.

The derivation of values for $E_{\mathrm{m}}$ in the present study required interpolation between recorded values at zero energy intake and levels of MEI above maintenance. Therefore, caution must be applied until further data sets are available close to and below zero energy retention. However, the constraints described by Webster (1978) indicate the difficulty inherent in any measurement of 'true' maintenance requirement for the growing animal.

With respect to the overall changes in RE with increments of MEI, the analysis of unscaled values (Table 5) indicated no significant differences between forage species. The divergence of the curves at higher increments of MEI, however, indicated a potential difference in RE and $k_{\mathrm{f}}$. Parallel curve analysis showed that the curves were significantly different, thus permitting examination of differences between the parameters $R E$ and calculated $k_{\mathrm{f}}$ (eqn (2)) at given points on the curve in relation to MEI. In this respect, a significant between-forage difference was indicated with the rate of decline in RE being greater for diet $\mathrm{G}$ compared with diet $\mathrm{C}$ at increasing levels of $\mathrm{MEI}$, which in turn accounted for the higher estimates of theoretical potential RE (parameter $P_{3}$, Table 5) obtained on $\operatorname{diet} \mathrm{C}$ compared with $\mathrm{G}$. Estimates of $k_{\mathrm{f}}$ (eqn (2)) were calculated from each forage curve at ascending increments of $\mathrm{MEI}$ which were calculated as multiples of an $E_{\mathrm{m}}$ value of $30.42 \mathrm{MJ} \mathrm{ME} / \mathrm{d}$ (derived from the mean of diets $\mathrm{G}$ and $\mathrm{C}$ ). This indicated that for a 
$240 \mathrm{~kg} \mathrm{LW}$ steer, when ME intakes were in excess of $1.65 E_{\mathrm{m}}$, significant differences in $k_{\mathrm{f}}$ were apparent between diets $\mathrm{G}$ and $\mathrm{C}(\mathrm{C}>\mathrm{G})$.

The apparently higher gross efficiency of $\mathrm{ME}$ utilization on diet $\mathrm{G}$, whilst not significantly different from diet $\mathrm{C}$ at levels of intake below $1.65 E_{\mathrm{m}}$, may result from differences in rumen fermentation patterns and changes in the proportions of energy yielding substrates absorbed (Beever et al. 1985).

Evidence of seasonal differences in $k_{\mathrm{f}}$ have been reported by Corbett et al. (1966) and Lonsdale \& Tayler (1971). Forage season effects were not specifically examined in the present study but owing to the extended feeding period required for the comparative slaughter technique, the forages could be considered as M- and L-season crops.

Exponential analysis of the data for effects of season were restricted by the limited number of data sets and the degree of interpolation required to incorporate FHP. Accordingly, the analysis was restricted to conventional linear methods within the limited range of MEI. The analysis revealed that both $\mathrm{MG}$ and $\mathrm{MC}$ had higher values for $k_{\mathrm{p}}(\mathrm{G} 0.51, \mathrm{C} 0.54)$ than LG and LC (G $0.42, C 0.42)$. However, the derivation of these values was associated with increased statistical errors and accounted for a lower proportion of variance compared with either linear or exponential analysis of the combined data range for each forage species.

The results of the experiment are in agreement with those of Rattray \& Joyce (1974) and confirm that $\mathrm{C}$ is potentially superior to $\mathrm{G}$ in terms of energy retention per unit MEI, but only at levels of feeding in excess of $1.65 E_{\mathrm{m}} / \mathrm{d}$ in this experiment. The theoretical potential, in terms of $\mathrm{RE}$, would appear greater for $\mathrm{C}$ than for $\mathrm{G}$, suggesting that nutrient availability was likely to limit first retention on $\operatorname{diet} \mathrm{G}$.

The reasons for differences between RE and $k_{\mathrm{p}}$, observed for the two forages, require additional knowledge concerning the nature and quantity of nutrients absorbed after digestion and the effect of nutrient interaction and hormonal status on nutrient utilization. Evidence relating to fat and protein tissue deposition in the animals used in the present study will be presented in a subsequent paper.

The results of the present study clearly demonstrate that the conclusions which can be drawn will be markedly influenced by the mathematical model adopted to describe the data. In the present study, acceptance of an exponential model was necessary to reconcile fully the data but was not intended to provide unequivocal proof that the relation between MEI and RE is best described by an exponential function. However, this form of analysis appears biologically credible and some support for this approach has been previously presented by Blaxter \& Boyne (1978) and more recently by Gill et al. (1984). The degree of interpolation required in the present study emphasizes the requirement for respiratory exchange measurements at additional levels of feeding in future experiments.

The authors would like to thank Miss C. Mearns, Miss K. Richardson, Miss K. Walker and $\mathrm{Mr} \mathrm{M}$. Walker for help given in the conduct of the experiment; Mr K. V. Skelton for assistance with instrumentation and data logging; Mr R. J. Barnes, Dr R. C. Siddons and Mr R. A. Terry for chemical analyses; Mr R. Dean and his staff for establishment and harvesting of the forage crops. The Grassland Research Institute is financed through the Agricultural \& Food Research Council and this work forms part of a commission from the Ministry of Agriculture, Fisheries and Food.

\section{REFER ENCES}

Agricultural Research Council (1980). The Nutrient Requirements of Farm Livestock no. 2. Ruminants. Farnham Royal: Commonwealth Agricultural Bureaux.

Beever, D. E., Thomson, D. J., Ulyatt, M. J., Cammell, S. B., Austin, A. R. \& Spooner, M. C. (1985). British Journal of Nutrition 54, 763-775. 
Blaxter, K. L. (1962). The Energy Metabolism of Ruminants. London: Hutchinson.

Blaxter, K. L. \& Boyne, A. W. (1970). In Energy Metabolism of Farm Animals, European Association for Animal Production Publication no. 13, pp. 9-13 [A. Schurch and C. Wenk, editors]. Vitznau, Switzerland; Juris Verlagzurich.

Blaxter, K. L. \& Boyne, A. W. (1978). Journal of Agricultural Science, Cambridge 90, 47-68.

Blaxter, K. L. \& Graham, N. McC. (1955). Journal of Agricultural Science, Cambridge 46, 292.

Brierem, K. (1953). Tid Sskrift For Det Norske Landbruk 60, 25.

Brouwer, E. (1965). In Energy Metabolism, European Association for Animal Production Publication no. 11, pp. 441-443 [K. L. Blaxter, editor]. London \& New York: Academic Press.

Cammell, S. B. (1977). Technical Report no. 24. Hurley: Grassland Research Institute.

Cammell, S. B., Beever, D. E., Skelton, K. V. \& Spooner, M. C. (1981). Laboratory Practice 30, 115-119.

Cammell, S. B., Beever, D. E., Thomson, D. J., Austin, A. R., Losada, H. R., Evans, R. T., Spooner, M. C. \& Terry, R. A. (1983). Animal Production 36, 501.

Corbett, J. L., Langlands, J. P., McDonald, I. \& Pullar, J. D. (1966). Animal Production 8, 13-27.

Efron, B. (1979). Annals of Statistics 7, 1-26.

Gibb, M. J. \& Treacher, T. T. (1983). Animal Production 37, 433-440.

Gill, E. M., Black, J. L., Thornley, J. H. M., Oldham, J. D. \& Beever, D. E. (1984). British Journal of Nutrition 52, 621-649.

Joyce, J. P. \& Newth, R. P. (1967). Proceedings of the New Zealand Society of Animal Production 27, $166-180$.

Lonsdale, C. R. \& Tayler, J. C. (1971). Animal Production 13, 384.

MacRae, J. C. \& Ulyatt, M. J. (1974). Journal of Agricultural Science, Cambridge 82, 309-319.

Neal, H. D. St. C., Thomas, C. \& Cobby, J. M. (1984). Journal of Agricultural Science 103, 1-10.

Rae, A. J., Brougham, B. W., Glenday, A. C. \& Butler, G. W. (1963). Journal of Agricultural Science, Cambridge 61, 187-190.

Rattray, P. V. \& Joyce, J. P. (1974). New Zealand Journal of Agricultural Research 17, 401-408.

Rogers, G. L., Porter, R. H. D. \& Robinson, I. (1979). Dairy Production Research Report, pp. 59-60. Victoria, Australia: Department of Agriculture, Division of Animal Research.

Siddons, R. C. \& Paradine, J. (1981). Journal of the Science of Food and Agriculture 32, 973-981.

Thomson, D. J. (1979). In Changes in Sward Composition and Productivity, British Grassland Society, Occasional Symposium No. 10, pp. 101-109 [A. H. Charles and R. J. Haggar, editors]. York: British Grassland Society.

Thomson, D. J., Beever, D. E., Haines, J. J., Cammell, S. B., Evans, R. T., Dhanoa, M. S. \& Austin, A. R. (1985). Journal of Dairy Research 52, 17-31.

Thomson, D. J., Haines, M. J., Austin, A. R., Cammell, S. B., Beever, D. E., Dhanoa, M. S. \& Barnes, R. L. (1983). Animal Production 36, 501

Tilley, J. M. A. \& Terry, R. A. (1963). Journal of the British Grassland Society 18, 104-111.

Ulyatt, M. J., Beever, D. E., Thomson, D. J., Evans, R. T. \& Haines, M. J. (1980). Proceedings of the Nutrition Society 39, 67A.

Ulyatt, M. J, Lancashire, J. A. \& Jones, W. R. (1977). Proceedings of the New Zealand Grassland Association 38, 107-118.

Van Es, A. J. H. (1961). Verslagen van Landbouwkundige Onderzoekingen 67, 5.

Vercoe, J. E. \& Frisch, J. E. (1974). In Energy Metabolism of Farm Animals, European Association for Animal Production Publication no. 14, pp. 131-134 [K. H. Menke, H.-J. Lantzsch and J. R. Reichl, editors]. Hohenheim: Universitat Hohenheim Dokumentationsstelle.

Webster, A. J. F. (1978). World Review of Nutrition and Dietetics 30, 189-226.

Webster, A. J. F., Brockway, J. \& Smith, J. S. (1974). Animal Production 19, 127-139. 